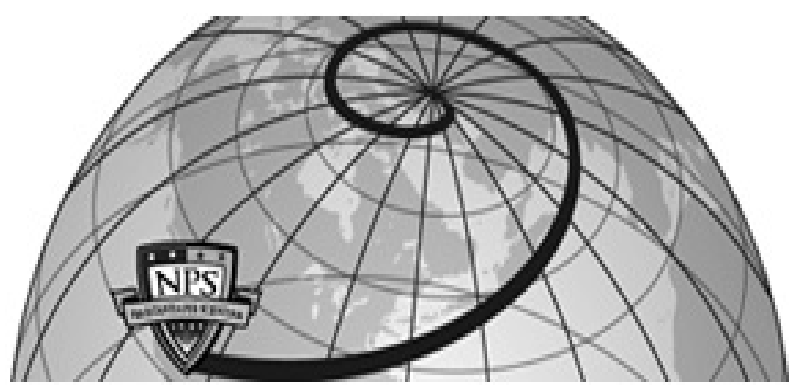

Calhoun: The NPS Institutional Archive DSpace Repository

Trade Policy Strategies and Enforcement

Choices: An examination of the 1992 Steel Antidumping Cases

Brook, Douglas A.

The International Trade Journal, Volume XVII, No. 1, Spring 2003, DOI:10.1080/08853900390152818 https://hdl.handle.net/10945/44476

This publication is a work of the U.S. Government as defined in Title 17, United States Code, Section 101. Copyright protection is not available for this work in the United States.

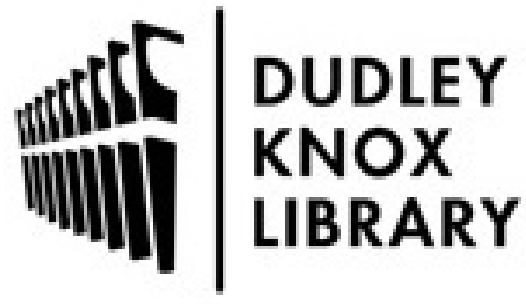

http://www.nps.edu/library
Calhoun is the Naval Postgraduate School's public access digital repository for research materials and institutional publications created by the NPS community. Calhoun is named for Professor of Mathematics Guy K. Calhoun, NPS's first appointed -- and published -- scholarly author.

Dudley Knox Library / Naval Postgraduate School 411 Dyer Road / 1 University Circle Monterey, California USA 93943 


\section{TRADE POLICY STRATEGIES}

\section{AND ENFORCEMENT \\ CHOICES: An Examination of the 1992 Steel Antidumping Cases}

\section{Douglas A. Brook}

\section{INTRODUCTION}

The decade of the 1990s was marked by significant changes in trading regimes around the world. New regional trading blocs, such as the European Community and the North American Free Trade area, emerged; traditional trade barriers, primarily tariffs, were substantially reduced or are headed toward elimination; many quotas and voluntary export restraints have expired; and, the Uruguay Round of global trade negotiations concluded in 1993 with new rules and a new World Trade Organization. These developments suggested an inexorable movement toward freer and more open trade. But, as the more recognizable trade barriers disappeared, administered trade became proportionately more important. "The reductions in tariffs have led governments to resort to other practices which constrain trade, and the restriction most often applied is antidumping law" (Anderson et al., 1995, p. 321).

An examination of the workings of U.S. antidumping laws, and the effects they have for the industries that use them, can help to explain what is at stake in the policy debates

Douglas A. Brook is Dean and Professor of Public Policy at the Graduate School of Business and Public Policy at the Naval Postgraduate School, Monterey, California. 
over their continued use. This paper explores the use of U.S. antidumping statutes by the domestic integrated steel industry. Steel is selected because it is the largest user of U.S. antidumping laws. The massive set of trade cases brought by the steel industry in 1992 offers an opportunity to explore the strategies, effects, and benefits associated with antidumping laws.

If antidumping cases are effective, as the steel industry must believe, changes in the level and pattern of imports should be discernible. An analysis of import data will determine if imports declined in products where antidumping duties were assessed. Further analysis will explore whether imports shifted to products not covered by antidumping decisions. Finally, import data is examined to determine if there was an apparent effect on imports from the mere filing of cases, regardless of the ultimate outcome.

The implications for U.S. trade policy and for policy choices in trade law enforcement are examined by looking at the initial determinations of dumping margins by the Department of Commerce and the final decisions of the International Trade Commission. Questions of discretion in trade law enforcement are also considered.

\section{LITERATURE REVIEW}

Economists have found it difficult to understand why some trade policies are chosen over others. A political economy approach attempts to combine economic analysis with political explanations for trade policy decisions. "Many economists have turned their attention to attempting to understand the "political economy' of protection, by which is meant the actual determinants of which industries receive protection, and of the structure of protection across industries" (Kruger, 1996, p. 2).

Kruger (1996) examined the key political economy questions-- why do governments choose trade policies that are eco- 
nomically inefficient? Why are lower cost alternatives not chosen? In a collection of essays, these questions are applied to recent examples in specific industries, including semiconductors, steel, automobiles, textiles, lumber, and agriculture. These essays test hypotheses about the effects on trade policy of such factors as political strength, industry cohesiveness, past protection, and national economic interest. The first three are found to be predictors of industry effectiveness in seeking protection. National economic interest is the language of the trade policy debate.

Rodrick (1996) presented a survey of political economy models, asking why trade policies are universally biased against trade? Four models are described: the tariff formulation function approach, the political support function approach, the median voter approach, and the campaign contributions approach. The first is criticized for a lack of consideration for the preferences of politicians, the second as lacking concern for the actions taken by influential groups, the third as lacking realism, and the fourth for ignoring other contributing factors. Rodrick concluded that higher levels of protection exist when the following conditions are present: labor-intensive, low-wage, low-skill industries; high and increasing import penetration; and a regionally concentrated industry. This is clearly descriptive of the steel industry in the 1990s.

A similar approach, applied specifically to the steel industry by Lanway, Morck, and Yeung (Lenway et al., 1996) argued that protection is sought because it results in greater private returns for steel shareholders, higher wages for steelworkers, and bigger pay increases for steel CEOs.

Still, Rodrick admitted there is "a serious gap in our understanding of what makes trade policy so inefficient when considerably more direct means of redistributing income exist" (1996, p. 471). This question was addressed by Moore (Kruger, 1996, 
pp. 73-132), explaining both the economic conditions and the political strengths of the steel industry; attributing steel's policy successes to a "steel triangle" of steel mills, the steelworkers union, and powerful lawmakers representing steel-making constituencies. As the industry has restructured, Moore observes a weakening of its political strength and suggests more limited policy effectiveness will result.

Staiger et al. (1994) studied the non-duty effects on imports of antidumping cases in the 1980s, finding that the investigation phase of antidumping petitions and any subsequent suspension agreement reduced imports. On the other hand, withdrawal of cases had no effect on imports. From this, it is concluded there are two types of filers of antidumping petitions:

(1) "outcome" filers who intend for the entire antidumping process to be followed and ultimately for duties to be assessed; and

(2) "process" filers who seek trade inhibiting effects from initiation of antidumping investigations.

Reitzes (1993) found that the threat of antidumping enforcement may alter strategic behavior under imperfect competition. Firm behavior may be altered by the mere threat of antidumping enforcement (1993). Administration of the trade laws is addressed in Anderson (1993) and Moore (1992) by exploring the question of discretion on the part of ITC commissioners. Mixed evidence is found about whether policy preferences and political considerations combine with statutory authority in framing ITC decisions.

\section{DUMPING AND THE ANTIDUMPING LAWS}

What is meant by "dumping" and how do the U.S. antidumping laws work? The first antidumping law in the United States was adopted in 1916. Today's antidumping laws derive from the 
1921 Antidumping Act. That law provided for imposition of a special duty when the secretary of the treasury "determined that a U.S. industry was being or was likely to be injured or prevented from being established by imports of a product at a price below its fair value in the exporting country or in other export markets" (Finger, 1993). Since 1921, antidumping law has grown in its technicality and its intricacies are beyond the scope of this paper. Simpler explanation suffice, however, to understand the policy questions involved and to facilitate an examination of the effects of antidumping policies.

Essentially, dumping is the introduction of imported goods into the United States at prices less than some "fair" standard. There are two types of dumping. Price to price dumping occurs when the foreign market price is less than the home market price. This type of dumping tactic may be used to achieve full or efficient plant utilization while maintaining high price levels in the home market. Below cost dumping occurs when the sales price in the foreign market is less than the cost of production. This form of dumping relies on home market structural characteristics such as government subsidies, the ability to cross-subsidize losses with profits from other business units, or access to unusually large financial resources.

As initially established in the 1921 law, a successful antidumping action must prove two elements. First, it must demonstrate that dumping has occurred. Second, it must prove that injury or the threat of injury has resulted from that dumping. The U.S. antidumping statutes are administered and enforced by the Department of Commerce and the International Trade Commission (ITC). These two agencies have complementary, but very different functions that lead them, as will be shown below, to very different conclusions about dumping practices.

Upon the initiation of an antidumping case by a petitioner (the Government can self-initiate, as well, but this is extremely rare), the Department of Commerce undertakes an investigation 
to determine whether dumping has occurred. If its investigation shows that dumping has occurred on certain products, commerce calculates the dumping margins, that is, the amount of underpricing, and assesses provisional dumping duties on imports for which bonds must be posted pending the final ruling of the ITC. The ITC has the responsibility to determine the second half of the antidumping equation--injury. The Commissioners must determine whether injury, or the threat of injury, has occurred as a result of the dumping. If an injury determination is made, permanent antidumping duty orders are issued, subject to a WTO-mandated five-year sunset review.

Why is antidumping an attractive trade policy choice? Finger offers the most concise representation of the major criticisms of antidumping: "it is not public policy, it is private policy. It is a harnessing of state power to serve a private interest: a means by which one competitor can use the power of the state to gain an edge over another competitor" (Finger, 1993). Cunningham, on the other hand, says this view ignores a fundamental underpinning of U.S. trade law and policy; "Certain practices are viewed as being unfair, and thus justifying measures to offset the unfairness, simply because they are wrong ... inherently distortive of the competitive position of the foreign exporter" (Cunningham, 1998, p. 5).

Regardless of this debate, antidumping has become an attractive policy choice for at least four reasons. First, antidumping is not necessarily seen as being "protectionist." Instead, antidumping is supported on the "fairness" argument. Second, antidumping involves a process that is at least quasi-judicial and akin to the concepts of regulated fair competition in the domestic economy. Third, antidumping recognizes that different countries have different policies regarding international competition. For some policy makers therefore, antidumping statutes are the quid pro quo for freer trade. Fourth, antidumping laws can be used as 
leverage in international negotiations. Antidumping laws "can work to promote open markets, expand trade and put an end to mercantilism and protectionism" (Mastel, 1966).

Who uses antidumping laws? Antidumping cases are brought by a wide variety of industries. "While cases involving steel products, semiconductors, and automobiles get the headlines, the typical petitioners are manufacturers of such products as canned clams or birch three-ply doorskins" (Cunningham, 1998, p. 7). In the European Community, a compilation of antidumping cases in the 1980s shows 93 cases brought by industrial chemical companies, 41 steel cases, 31 in synthetic fibers, and 10 in consumer electronics (Hindley and Messerlin, 1996). "Extensive use is being made of such provisions. (B)etween 1980 and 1988, thirteen trading countries initiated a total of 1665 antidumping investigations" (Tharakan, 1991, p. 1).

\section{STEEL PROTECTION}

The worldwide history of steel is characterized by a high degree of politicization and a particular vulnerability to controversial trading practices. "The intrusion of the state into this sector has produced a trading environment characterized by cartels, highly restrictive import regimes, subsidies and dumping" (Howell et al., 1988, p. i). In the United States, the last three decades have seen the decline and restructuring of the domestic steel industry. The decline was largely blamed on unfair foreign competition.

The integrated steel industry and its allies have argued that unfair foreign competition is the principal source of the industry's economic decline. This argument has been bolstered by the widely acknowledged presence of pervasive foreign government steel subsidies. These subsidies, 
combined with a structural slowdown in world steel demand, have contributed to worldwide overcapacity. Foreign firms, the steel industry has argued consistently, have dealt with this overcapacity by 'dumping' excess production into the United States (Moore, 1996, p. 449).

There is debate over this proposition, of course. Some observers place the blame for the decline of American steel on its failure to modernize and its insulation from competition, not on trade. "The sources of change and competitive shifts in the world steel industry have in fact many roots; trade is not the sole, or even the primary, reason for the crisis" (Jones, 1996, p. 157). For this study, however, it is only important that the domestic integrated steel industry believes that its problems are rooted in unfair foreign competition, that "steelmakers, in fact, are locked in a protracted competitive struggle, one that will ultimately determine just where steel is to be made" (Hogan, 1994, p. 1). Thus, steel has sought protection.

The period from 1969 to 1990 was an era of industry-specific protection for the American steel industry. From 1969 to 1974, voluntary restraint agreements (VRAs) were negotiated with European and Japanese exporters. In 1977, a trigger price mechanism was instituted for all steel products. This involved "a 'reference price' system that would serve as a basis for monitoring imports to determine if there was prima facie evidence of dumping" (Crandall, 1981, p. 43). Negotiation of successively broader rounds of steel VRAs began in 1982. Two rounds of VRAs predominated. The first, from 1984 to 1989, set the market share for participating nations at 18.4 percent. The second, from 1989 to 1992, comprised President Bush's "Steel Liberalization Program" - a two and one-half year VRA extension; gradual increase in market share to 20.9 percent; and negotiation of a Multilateral Steel Agreement (MSA) to eliminate "trade 
distorting" practices in steel (Moore, 1996). The TPM and the VRAs were rooted in antidumping actions. "Voluntary export agreements are the outcome of negotiations that originate as antidumping actions or other forms of administered protection" (Rosendorff, 1996, p. 544). The steel TPM scheme "arose with a rash of antidumping suits and culminated in the announcement of the introduction of the trigger price mechanism" (Jones, 1986, p. 83).

In April 1992, the VRAs were terminated, even though the MSA negotiations had broken down over the question of allowable subsidies. Without specific protection, the steel industry had only the generic trade laws to use to counter dumped or subsidized steel. Curtis H. Barnette, chairman and CEO of Bethlehem Steel, thus referred to the 1990s as the "era of trade law remedies" (Brook, 1998). He argued that when the VRAs expired, the Bush Administration "explicitly stated that the U.S. steel industry should thereafter rely on existing unfair trade remedies" (Barnette, 1994, p. 4). In June 1992, the steel industry filed the largest set of antidumping cases in history.

\section{THE 1992 STEEL TRADE CASES}

On June 30, 1992, 12 U.S. steel producers and the steelworkers union filed 48 antidumping cases against 21 foreign countries. There were also 36 countervailing duty cases filed against subsidized foreign steel. Together this was a record 94 cases brought by a single industry seeking trade law remedies. ${ }^{1}$

The cases were brought in four categories of carbon steel products: hot rolled flat products, cold rolled flat products,

\footnotetext{
${ }^{1}$ This article concentrates on antidumping, but the way in which these cases were adjudicated does not always allow a clear separation of the data between antidumping cases and CVD cases. When both are included in the statistical data, it will be noted.
} 
corrosion-resistant flat products, and cut-to-length plate. Hot rolled steel is the first level finished product of a steel mill. It is sold in coils and used as is, or subjected to further processing. Cold rolled products represent the next level of processing, a first stage of adding value to a hot rolled product by, for instance, altering its width or thickness to customer specifications. Corrosion-resistant steel is a higher value-added product, having been coated or chemically treated for rust resistant applications such as automotive hoods and doors or home appliances. Cut-to-length plate is steel plate sized to customer specifications, another value-added product.

The combined antidumping and countervailing duty (CVD) cases involved 6.5 million tons of 1991 imports in these categories of products, with a landed value of about $\$ 3.0$ billion. Total U.S. apparent consumption of these products in 1991 was 45.5 million tons. ${ }^{2}$ The countries involved were Argentina, Australia, Austria, Belgium, Brazil, Canada, Finland, France, Germany, Italy, Japan, South Korean, Mexico, Netherlands, New Zealand, Poland, Romania, Spain, Sweden. Taiwan, and the United Kingdom.

The petitioning companies alleged antidumping margins ranging from a high of 177 percent for hot rolled products from Poland to a low of 1.52 percent for plate from Belgium. In August, 1992 the ITC ruled on a preliminary basis that there was a reasonable indication of injury to U.S. steelmakers from imports and it allowed 72 of the $84 \mathrm{AD}$ and CVD cases against 20 of the 21 original countries (all but Taiwan) to proceed to further investigation. Nineteen (all except New Zealand) involved allegations of dumping. In June, 1993, the Commerce Department completed its investigation and announced its final antidumping margins. These findings are shown in Table I.

${ }^{2}$ Source: American Iron and Steel Institute. 
Table I

Department of Commerce Final Antidumping Margins

\begin{tabular}{|c|c|c|c|c|}
\hline Country & Hot Rolled & Cold Rolled & Corrosion Resistant & Plate \\
\hline Argentina & & 51.58 & & \\
\hline Australia & & & 24.96 & \\
\hline Austria & & 18.11 & & \\
\hline Belgium & 41.98 & 14.73 & & 6.75 \\
\hline Brazil & 71.48 & 70.59 & 43.00 & 75.54 \\
\hline Canada & 20.84 & 36.19 & 22.29 & 61.95 \\
\hline Finland & & & & 32.25 \\
\hline France & 79.54 & 75.33 & 44.40 & 52.87 \\
\hline Germany & 29.02 & 19.52 & 4.88 & 35.36 \\
\hline Italy & & 50.15 & & 53.88 \\
\hline Japan & 26.51 & 32.18 & 40.19 & \\
\hline South Korea & 8.19 & 14.53 & 17.88 & 7.87 \\
\hline Mexico & & & 64.80 & 49.25 \\
\hline Netherlands & 30.70 & 20.09 & & \\
\hline Poland & & & & 61.98 \\
\hline Romania & & & & 75.04 \\
\hline Spain & & 43.12 & & 105.61 \\
\hline Sweden & & & & 24.23 \\
\hline United Kingdom & & & & 109.22 \\
\hline
\end{tabular}

Source: U.S. International Trade Commission. August 1993. Publication 2664.

Two months later, the ITC issued its final determination of injury and entered antidumping and CVD duties for certain countries and products that were determined to be engaging in injurious dumping. These determinations are shown in Table II.

As can be seen, the ITC final decisions resulted in a mixed verdict for the steel industry. Generally, the ITC voted affirmatively for the industry in cases involving most of the plate and corrosion resistant cases, a few of the cold rolled cases and in none of the hot rolled cases, notwithstanding the determination of substantial dumping margins in these cases by the Department of Commerce. Final antidumping duties were ordered for the products with affirmative ITC votes. 
Table II

ITC Final Determination on Antidumping and CVD Cases

\begin{tabular}{|c|c|c|c|c|}
\hline Country & Hot Rolled & Cold Rolled & Corrosion Resistant & Plate \\
\hline Argentina & & $\mathrm{N}$ & & \\
\hline Australia & & & $\mathrm{Y}$ & \\
\hline Austria & & $\mathrm{N}$ & & \\
\hline Belgium & $\mathrm{N}$ & $\mathrm{N}$ & & $\mathrm{Y}$ \\
\hline Brazil & $\mathrm{N}$ & $\mathrm{N}$ & $\mathrm{N}$ & $\mathrm{Y}$ \\
\hline Canada & $\mathrm{N}$ & $\mathrm{N}$ & $\mathrm{Y}$ & $\mathrm{Y}$ \\
\hline Finland & & & & $\mathrm{Y}$ \\
\hline France & $\mathrm{N}$ & $\mathrm{N}$ & $\mathrm{Y}$ & $\mathrm{N}$ \\
\hline Germany & $\mathrm{N}$ & $\mathrm{Y}$ & $\mathrm{Y}$ & $\mathrm{Y}$ \\
\hline Italy & & $\mathrm{N}$ & & $\mathrm{N}$ \\
\hline Japan & $\mathrm{N}$ & $\mathrm{N}$ & $\mathrm{Y}$ & \\
\hline South Korean & $\mathrm{N}$ & $\mathrm{Y}$ & $\mathrm{Y}$ & $\mathrm{N}$ \\
\hline Mexico & & & $\mathrm{N}$ & Y \\
\hline Netherlands & $N$ & $\mathrm{Y}$ & & \\
\hline Poland & & & & $\mathrm{Y}$ \\
\hline Romania & & & & $\mathrm{Y}$ \\
\hline \multicolumn{5}{|l|}{ South Africa } \\
\hline Spain & & $\mathrm{N}$ & & $\mathrm{Y}$ \\
\hline Sweden & & & $\mathrm{N}$ & $\mathrm{Y}$ \\
\hline United Kingdom & & & & $\mathrm{Y}$ \\
\hline
\end{tabular}

Source: Author. Based on data provided by the U.S. International Trade Commission.

What effects did the cases have on imports for these categories of steel products? Expectations would be that imports of steel products covered by antidumping duties would fall upon filing of the cases and then either fall or rise depending upon the final outcome of the ITC deliberations.

The data show that this is in fact the case. As shown in Table III, imports of all products fell upon the filing of cases and preliminary determination of dumping. Plate imports fell precipitously from 13.8 percent of apparent domestic consumption (ADC) in 1992 to only 2.8 percent in 1993. Likewise, imports of corrosion resistant products fell from 14.0 percent to 6.2 percent of ADC. Cold rolled imports fell from 4.9 percent to 4.0 percent and hot rolled imports dropped from 17.5 to 14.2 percent. 
Table III

Import Penetration of Covered Steel Products

\begin{tabular}{lcccr}
\hline & \multicolumn{4}{c}{ Percent of Apparent Domestic Consumption } \\
\cline { 2 - 5 } Year & Hot Rolled & Cold Rolled & Corrosion Resistant & Plate \\
\hline 1989 & 14.8 & 3.0 & 12.0 & 13.5 \\
1990 & 15.9 & 4.0 & 11.9 & 13.7 \\
1991 & 16.0 & 4.0 & 12.1 & 13.9 \\
1992 & 17.5 & 4.9 & 14.0 & 13.8 \\
1993 & 14.2 & 4.0 & 6.2 & 2.8 \\
1994 & 21.3 & 3.5 & 4.5 & 2.0 \\
1995 & 17.5 & 1.9 & 3.0 & 1.0 \\
1996 & 21.9 & 1.2 & 2.8 & 2.1 \\
1997 & 23.8 & 1.0 & 2.9 & 1.8 \\
\hline
\end{tabular}

Source: Dewey-Ballantine, LLP. Compiled from U.S. Department of Commerce data and American Iron and Steel Institute, Annual Statistical Reports.

What about after the cases have been decided? Most of the affirmative determinations by the ITC were in cut-to-length plate and corrosion resistant products. Imports in both categories continued to fall. Plate imports slid from 2.8 percent of apparent domestic consumption in 1993 to 1.8 percent in 1997. Corrosion resistant imports similarly dropped from 6.2 percent in 1993 to 2.9 percent in 1997. Even cold rolled products, on which there were fewer duties imposed, continued to fall from 4.0 percent in 1993 to 1.0 percent in 1997. Hot rolled products, however, indicate a different pattern. With no antidumping orders from the ITC, imports of hot rolled products surged from 14.2 percent in 1992 to 21.3 percent in the year immediately following the ITC's ruling. Hot rolled imports continued to climb to 23.8 percent of the market in 1997.

Another way to look at the impact of the case determinations would be to compare imports of similar products from countries that were covered by orders to those from countries not covered. This comparison offers two useful points of analysis. First, the countries not covered by final antidumping orders provides a 
sort of control group against which change in imports from the covered countries can be compared. If imports had fallen in both groups, for instance, it could be inferred that antidumping orders were not responsible for the reduction in imports from the covered countries. This is not the case, however. As shown in Table IV, imports from countries not covered surged immediately after the final ITC rulings and have continued to grow. Imports from covered countries, on the other hand, fell during the investigation stage of the cases, dropped more after the ITC determinations, and continued to slide in subsequent years.

A second way to look at the data in Table IV is to consider the trend in total imports from both covered and non-covered countries. Total imports for all sources of cold rolled and plate products were fairly steady, increasing slightly each year until the cases were filed. After 1993, however, import increases from noncovered countries more than offset the decreases from covered countries. Non-covered imports of cold rolled steel increased by

Table IV

Imports from Covered and Non-Covered Countries

\begin{tabular}{lcccc}
\hline & \multicolumn{3}{c}{ Percent of Apparent Domestic Consumption } \\
\cline { 2 - 3 } & \multicolumn{2}{c}{ Cold Rolled } & \multicolumn{2}{c}{ Plate } \\
\cline { 2 - 3 } \cline { 5 - 5 } Year & Covered & Non-Covered & Covered & Non-Covered \\
\hline 1989 & 3.0 & 9.0 & 13.5 & 3.5 \\
1990 & 4.0 & 9.0 & 13.7 & 3.4 \\
1991 & 4.0 & 9.1 & 13.9 & 3.2 \\
1992 & 4.9 & 8.6 & 13.8 & 4.0 \\
1993 & 4.0 & 7.5 & 2.8 & 9.1 \\
1994 & 3.5 & 17.5 & 2.0 & 17.5 \\
1995 & 1.9 & 13.5 & 1.0 & 22.6 \\
1996 & 1.2 & 13.6 & 2.1 & 18.5 \\
1997 & 1.0 & 18.5 & 1.8 & \\
\hline
\end{tabular}

Source: Dewey-Ballantine, LLP. Compiled from U.S. Department of Commerce data and American Iron and Steel Institute, Annual Statistical Reports. 
9.9 percent of ADC from 1992 to 1997 , overwhelming the 3.9 percent decrease in covered products from 1992 to 1997. Covered imports of plate dropped from 13.8 percent of ADC to 1.8 percent between 1992 and 1997 but non-covered steel imports increased during the same period from 4.0 percent to 18.5 percent, an increase of 14.5 percent compared to a decrease of 13.0 percent. Total imports surged after the ITC ruled and remained at levels higher than they were before the cases were brought.

So, as expected, imports did fall as a result of affirmative decisions by the ITC. In all categories of products and countries covered by the final ITC orders imports fell and continued at low levels after the decisions were announced. That these reduced imports were the result of the antidumping actions, and not from some other cause, is supported by the comparative data showing imports of like products from countries not covered increasing after the final ITC orders.

There is also a plausible inference that imports shifted to products not subject to antidumping duties. This is suggested by the increase in hot rolled imports after the ITC ruling. After the 1993 ITC decisions, imports of hot rolled steel surged from 14.2 percent to 21.3 percent of ADC, while imports of cold rolled, corrosion resistant, and plate continued to fall. This suggests that covered countries may have shifted their export strategies.

It also appears that the filing of cases with the subsequent investigation by the Department of Commerce has a chilling effect on imports. All four categories of steel products show a marked drop in imports after the cases were filed in 1992. Those that were subsequently subject to antidumping duty orders by the ITC remained low while others rose. Thus there does seem to be a "process filing" effect where imports fall simply as a result of initiating the process of antidumping cases. Even though preliminary duties are refundable in the event of a negative determination by the ITC, exporters and 
importers seem immediately to change their behavior while the antidumping process is underway.

What was the effect of the cases on the health of the industry? The American steel industry lost massive amounts of money in the 1980 s and early 1990s. Its largest losses were over $\$ 4$ billion in 1986 and 1992 and over $\$ 2$ billion in 1991. An abrupt turnaround occurred between 1992 and 1993, an upswing of nearly $\$ 6$ billion. This sudden turnaround in 1992-1993 suggests that filing trade cases with the resulting "process filing" effect had positive consequences for industry profitability. An even more direct effect of trade cases was seen in the changes in stock prices. On the other hand, when the ITC decisions were announced in 1993, the industry lost $\$ 1$ billion in market capitalization or over ten percent of its total stock value. Investors apparently saw the mixed ITC decision as a setback for the industry.

What is to be concluded from all of this data. First, the steel industry intended to be an "outcome filer" and, in fact, it did prosecute the cases to their conclusion without any attempt at negotiated settlements. Its biggest gain came, however, as a "process filer." The greatest reduction in imports, and the highest industry profitability occurred while the cases were being investigated and decided, not after the decisions were rendered.

\section{TRADE POLICY ENFORCEMENT CHOICES}

Enforcement of the antidumping laws depends on the final determinations by the ITC. As has been seen in the steel cases, the ITC can render decisions that are at variance with what the Commerce Department's findings would suggest they should be. Unlike the Commerce Department, which is concerned only with whether and to what extent dumping exists, the ITC must also find injury or the threat of injury. In determining injury, the ITC is directed by statute to look at the effects of imports 
Table V

ITC Votes on 1992 Steel Petitions

\begin{tabular}{lccc}
\hline Commissioner & Affirmative & Negative & Affirmative \% \\
\hline Nuzum (D) & 30 & 14 & $68 \%$ \\
Newquist (D) & 27 & 17 & $61 \%$ \\
Rohr (D) & $\underline{24}$ & $\underline{20}$ & $\underline{55 \%}$ \\
$\quad$ Total & 81 & 51 & $61 \%$ \\
\hline Watson (R) & 18 & 24 & $43 \%$ \\
Crawford (R) & 13 & 31 & $30 \%$ \\
Brunsdale (R) & $\underline{7}$ & $\underline{37}$ & $\underline{16 \%}$ \\
$\quad$ Total & 38 & 92 & $30 \%$ \\
\hline
\end{tabular}

Source: Author. Based on data provided by the U.S. International Trade Commission.

on 14 factors, such as sales, capacity utilization, profits, employment, and investment. Anderson studied discretionary models of ITC decisions and concluded that "statutory direction appears to be the primary force underlying antidumping decisions made by the ITC." He found "no evidence that commission decisions are based on political considerations not set forth in the statue" (1993, p. 928). Perhaps so, but the votes of the ITC commissioners on the steel cases suggests an interesting pattern of discretion and political alignment, as shown in Table V (Brook, 1998, p. 139).

One needs only to reflect upon the party breakdown in the votes of the ITC commissioners on the steel petitions to suggest that economic, political, or philosophical viewpoints can be exercised within the commission" statutory boundaries. How else, could two partisan groups of commissioners come to such distinctly different conclusions about enforcing the same trade laws based on the same information? What might be the effect on U.S. trade policy enforcement of a change in just one member of the commission? 


\section{CONCLUSION}

An examination of the steel industry's massive antidumping filing of 1992 has helped to address questions about why petitioners bring antidumping cases, how they are processed, and what their effects on imports can be. The data have shown that an inhibiting effect on imports can be achieved by the mere filing of credible cases. The data also show that affirmative antidumping decisions result in reductions in imports. On the other hand, import statistics reveal that surges in imports take place in products and from countries not covered by antidumping orders. In the example of the steel cases, these increases overcame any reductions in covered products. This suggests a relationship between profitability, trade cases, and import levels.

Policy preferences and statutory enforcement have also been examined relative to antidumping laws. The decisions by the ITC suggest the exercise of individual political or policy preferences.

Finally, although the steel industry intended to secure longterm relief as an "outcome filer," its greatest benefit came as a "process filer."

\section{NOTE}

The author gratefully acknowledges the assistance of Mark Paulson at the International Trade Commission, Thomas Sneeringer and the staff of the American Iron and Steel Institute, and Andrew Kentz and the staff of the Washington office of DeweyBallantine, LLP, for providing and compiling much of the data used in this paper. The author, of course, remains responsible for any errors or omissions.

\section{REFERENCES}

American Iron and Steel Institute. 1992-2001. Annual Statistical Report. Author, Washington, DC. 
Anderson, K. B. 1993. Agency Discretion or Statutory Direction: Decision Making at the U.S. International Trade Commission. Journal of Law and Economics 36(2):915-935.

Anderson, S. P., Schmitt, N., and Thisse, J.-F. 1995. Who Benefits from Antidumping Legislation? Journal of International Economics 38(3-4):321.

Barnette, C. H. 1994. Remarks at Paine-Webber Steel Trade Conference, New York, unpublished paper.

Brook, D. A. 1998. Steel: Trade Policy in a Changed Environment. In: Constituent Interests and U.S. Trade Policies, pp. 133-144. A. Deardorff and R. Stern, eds., University of Michigan Press, Ann Arbor.

Crandall, R. W. 1981. The U.S. Steel Industry in Recurrent Crisis: Policy Options in a Competitive World. Brookings Institution, Washington, D.C.

Cunningham, R. O. 1998. Trade Law and Trade Policy: The Advocate's Perspective. Constituent Interests and U.S. Trade Policies, pp. 5-15, A. Deardorff and R. Stern, eds. University of Michigan Press, Ann Arbor.

Dewey-Ballantine, LLP. 1992-1993. Various client reports. Washington, DC.

Finger, J. M. 1993. Antidumping: How It Works and Who Gets Hurt. The University of Michigan Press, Ann Arbor.

Gould, D. M. and Gruben, W. C. April 1997. Will Fair Trade Diminish Free Trade? Business Economics 32(2):7-10.

Hindley, B. and Messerlin, P. A. 1996. Antidumping Industrial Policy: Legalized Protectionism in the WTO and What to Do About It. AEI Press, Washington, DC.

Hogan, W. T. 1994. Steel in the 21 ${ }^{\text {st }}$ Century: Competition Forges

a New World Order. Lexington, New York.

Howell, T. R., Noellert, W. A., Kreier, J. G., and Wolf, A. W. 1988. Steel and the State, Westview Press, Boulder. 
Jones, K. A. 1986. Politics vs. Economics in World Steel Trade. Allen \& Unwin, London.

Kruger, A. O. 1996. The Political Economy of American Trade Policy, University of Chicago Press, Chicago.

Lenway, S., Morck, R., and Yeung, B. 1996. Rent-Seeking, Protectionism and Innovation in the American Steel Industry. The Economic Journal 106:410-421.

Mastel, G. 1966. American Trade Laws After the Uruguay Round. M. E. Sharpe, Armonk, NY.

Moore, M. 1992. Rules or Politics? An Empirical Analysis of ITC Antidumping Decisions. Economic Inquiry 30(3):449-466.

Moore, M. 1996. Steel Protection in the 1980s: The Waning Influence of Big Steel. In: The Political Economy of American Trade Policy, pp. 73-132, A. O. Kruger.

Reitzes, J. D. 1993. Antidumping Policy. International Economic Review 34(4):745-763.

Rodrick, D. 1996. Political Economy of Trade Policy. In: Handbook of International Economics, vol. 3. G. Grossman and K. Rogoff, eds. Elsevier, New York.

Rosendorff, B. P. 1996. Voluntary Export Restraints, Antidumping Procedures, and Domestic Politics. American Economic Review 86(3):544.

Staiger, R. W., Wolak, F. A., Litan, R. E., Katz, M. L., and Waverman, L. 1994. Measuring Industry-Specific Protection: Antidumping in the United States. Brookings Papers on Economic Activity 51-118.

Tharakan, P. K. M., ed. 1991. Policy Implications of Antidumping Measures, Elsevier Science Publishing Co., Amsterdam.

U.S. International Trade Commission. 1993. Certain Flat Rolled Carbon Steel Products, Volume II, Information Obtained in the Investigations. Publication 2664: pp. I14-I16. 
Copyright of International Trade Journal is the property of Taylor \& Francis Ltd. The copyright in an individual article may be maintained by the author in certain cases. Content may not be copied or emailed to multiple sites or posted to a listserv without the copyright holder's express written permission. However, users may print, download, or email articles for individual use. 